\title{
SOCIAL MEDIA LITERACY COUNSELING FOR PROSPECTIVE PROPAGATORS TO THWART HOAX INFORMATION
}

\author{
Haresti Asysy Amrihani' ${ }^{1}$ Rajab Ritonga² \\ ${ }^{1}$ Faculty of Social and Political Sciences, Airlangga University, Surabaya \\ ${ }^{2}$ Faculty of Comunication Science, LSPR Communication and Business Institute, Jakarta \\ Corresponding Author: haresti.asysy.amrihani-2021@fisip.unair.ac.id
}

\begin{abstract}
As social media users, university students often receive hoax news from social media platforms, such as Youtube, Facebook, Instagram, Twitter, Vlog and Whatsapp group. In this connection, they are expected not to forward hoax messages to fellow social media users so that the spread of hoax messages can be stopped at a university student level. To that end, this Dedication to the Public tries to provide counseling to students of the Faculty of Propagation and Communication at State Islamic University (UIN) Walisongo in Semarang. The method used to carry out the activity is counseling since the participants are students who are studying propagation and communication sciences. Therefore, many of them have a basic knowledge of propagation science which is necessary for them to become propagators in the future. More than 50 students, who are mostly students of the Faculty of Propagation and Communication and campus press activists of UIN Walisongo, participated in this counseling. This counseling ran dynamically through a discussion between the participants and source persons comprising a Central Java senior journalist, a commissioner of the Central Java Chapter of the Indonesia Broadcast Commission, and a lecturer of the Faculty of Propagation and Communication at UIN Walisongo. Among the result of the counseling is that the participants have understanding about the danger of spreading hoax news. The awareness not to spread hoax news is very important since the participants of the counseling are prospective propagators who also study communication science and are groomed to have a skill in producing propagation messages to the public. The participants are grateful for the counseling since it has broadened their outlook to understand the danger of hoax information.
\end{abstract}

Keywords: hoax danger, social media literacy, counseling, social media platform

\section{Introduction}

Digital technology has presented its users with space to hold communication and give information without border, time and distance constraints. This internet-based technology has become very popular in the community to receive and spread information through various platforms, such as youtube, facebook, instagram, twitter, and whatsapp group which have numerous users. According to data in 2018, the number of internet users in Indonesia reached 171.18 million, with Java Island occupying first place in terms of users. Meanwhile, 89.7 percent of internet users were university students and 97 percent of the users accessed various contents from social media (katadata.co.id, 16/5/2019, 12.58 WIB). The number of internet users rose sharply compared to the previous year. The Communication and Informatics Ministry revealed that the number of internet users in 2017 reached 143.26 million, accounting for 54.68 percent of the total Indonesian population (Kominfo, 2018).

Various online media platforms play a significant role in spreading information to readers. Fast and easy access make readers vie for information and then forward it to the accounts of their friends without selecting it. As a matter of fact, the contents received and forwarded are hoax information.

The easy internet access allows for easy flexibility and access, meaning that all people can use internet everywhere and anytime provided there is internet connection. Unlike one-way conventional media, new media is interactive. When it comes to new media marked by media convergence and interactivity, literacy is not only related to digesting the media content but also producing interactive texts in the context of hypermedia (Buckingham, 2006).

The research conducted by Mastel (2017) shows that website is mostly used to spread hoax news (34.90\%), followed by chatting (Whatsapp, Line, Telegram) at $62.80 \%$, and social media (Facebook, Twitter, Instagram) which are the much-accessed media at 92\%. Meanwhile, the data from the Communication and Informatics Ministry show that nearly 800 thousand sites in Indonesia are believed to have spread hoax news and hate speech (Pratama, 2016).

The survey conducted by Mastel shows 34.60\% of the respondents receive hoax news everyday, Nearly $14.70 \%$ of respondents disclosed that they received more than one hoax stories per day. Sometimes the same hoax story was received from more than one source. Meanwhile, $18.20 \%$ of the respondents received hoax news once a month, and $32.50 \%$ received hoax news once a week. The figures suggest massive spread of hoax news through various social media lines everyday.

In general, university students as the future generation are also exposed to hoax news they receive from their social media accounts, including those who are studying at the Faculty of Propagation and Communication at State Islamic University (UIN) Walisongo in Semarang, Central Java, to become propagators in the future. After completing their study, they will propagate Islamic teachings in the community. Therefore, it is important to give them understanding about the danger of hoax information from now on. This social media literacy counseling serves as a means to discuss hoaxes affecting them. 
This way the objective of Dedication to the Community is to provide its participants with knowledge about the danger of hoaxes. By understanding the ins and outs of hoaxes, they are expected to see what steps they must take when receiving hoax news, by stopping and deleting hoax news from their social media accounts. This counseling is also expected to enable the participants to explain to the public not to spread and produce hoax news when they complete their study and become propagators.

\section{Material and Methodology}

The challenges faced by new media do not rest merely with technology and industrial model. In digital media, there has been a shift in audience position from being passive to active audience that have freedom to produce text on their own thanks to the internet. On one hand, this privilege is affordances, while on the other hand it brings about pressure. This is because to be able to benefit from the affordances, one needs ability which is not merely related to the mastery of access and technology (Kurnia \& Astuti, 2017). For this part, hoax news emerge and spread to audience through a chain of communication from one account to another.

In the Oxford Learner's Dictionary, hoax is defined as a form of deceitfulness to make a joke or bring about danger, while in English dictionary hoax means a banter, fictitious story, and deceiving or cheating. In the book "Sins Against Science, The Scientific Media Hoaxes of Poe, Twain, and Others" written by Walsh (2006), the term hoax has existed since 1800 or the early days of industrial revolution in Britain. The word hoax has existed since hundreds of years, namely 'hocus' from charms 'hocus pocus', a phrase frequently used by conjurer, similar to 'sim salabim'. Boese (2002) in his book 'Museum of Hoaxes" wrote, the term hoax for the first time emerged in almanac or false calendar made by Isaac Bickerstaff in 1709 to predict the death of astrologist John Partidge.

Hoax influences everybody who reads it so that they believe the hoax they read is true as it is (Juditha, 2018). Someone who spreads hoax and makes the public trust the information, though it is not true, the person is called hoaxer.

The easy and massive spread of hoax news has raised the question of what really makes hoax news easily accepted in the public life. It turns out that the presence of smartphone as a multifunction communication means which is easily used to find and spread information plays a great role in spreading hoax. Numerous users of smartphone connected to the internet contribute to the easy, cheap and massive spread of hoax news.

On the other hand, the low literacy or laziness of readers to read full story from the original source causes them to rely on the headline of provocative news without reading its content which is frequently not relevant to the title (Marwan \& Ahyad: 2016). In fact, in many cases, hoax news comes from an unclear or unreliable source.
Basically, the public like sensational and horrendous news. Hoax is created to draw public sensation and attention. This is done by attracting many users to visit the site for the sake of economic advantage (Rahadi, 2017). Hoax is also created to influence and direct public opinion, towards the framing as expected by the writer of news story. Intentionally, hoax is produced to serve as a business opportunity by cooperating with those having social and political goals (Evelina, 2015).

Furthermore, some parties create hoax to corner and attack other individuals with the aim of giving bad impressions to them, widely known as a black campaign (Astrini, 2017). This includes creating hoax news to conduct psychological terror and cause public unrest and anxiety. This chaos is later capitalized on by irresponsible parties to receive economic and non-economic gains.

According to Rahadi (2017), hoax can be classified into: (1) Fake news, namely news designed to replace original news with the aim of falsifying news or inserting untruthfulness to news; (2) Clickbait, namely tweets placed strategically in a website with the aim of attracting people to visit other website. In general, content in the tweet accords with the fact but the title is made excessive or complete with attractive pictures to attract the reader to click the tweet; (3) Confirmation bias, namely the tendency to build confidence and find information supporting one's stand and ignore the existing contrast evidence; (4) Misinformation, namely wrong or inaccurate information particularly intended to deceive; (5) Satire, namely a text using humor, irony, an exaggerated thing to comment on an event; (6) Post truth, namely an incident where emotion plays a greater role than the fact to form public opinion; and (7) Propaganda, namely an attempt to influence public views by spreading a piece of information, either fact or semi-fact.

\section{Realization Method}

This media literacy in the form of counselling was conducted at the campus of Walisongo State Islamic University (UIN) in Semarang and attended by students of the Propagation and Communication Faculty and campus press activists of UIN Walisongo. In total, the number of participants was more than 50. Acting as source persons were a Central Java senior journalist, commissioner of the Central Java Chapter of the Indonesia Broadcast Commission and lecturer of the Faculty of Propagation and Communication at UIN Walisongo.

This counseling was conducted on September 1213, 2018 and attended by more than 50 students. The training was opened by Chief of Islamic Communication and Broadcast at UIN Walisongo, Siti Solihati, who later spoke of the negative impact of hoax news in social media by explaining in details social media platforms such as Facebook, Twitter, Instagram, YouTube, and Vlog. She later highlighted the impact of hoax news spread by social media. 
According to Siti Solihati, the activity was aimed at making students accustomed to using media in a healthy manner and preparing them to become agents and create agents to push media literacy in the community. Hopefully, this activity will arouse awareness and collective responsibility to supervise media, build media literacy culture and use media wisely.

\section{Result and Discussion}

This social media literacy counseling highlights seven media literacy skills: (1) Analysis, namely the ability to understand hoax, uncover and study a message or information from a media outlet; (2) evaluation, namely the ability to evaluate hoax information; (3) Grouping, namely, the ability to classify a lot of information obtained; (4) Induction, namely the ability to analyse and assess hoax comprehensively; (5) Deduction, namely the ability to analyse and assess general information and turn it into special information; (6) Synthesis, namely, the ability to change information from media into a message in new structure which is different from earlier; and (7) Abstracting, namely, the ability to analyse, describe and find the point of problems in order to understand it.

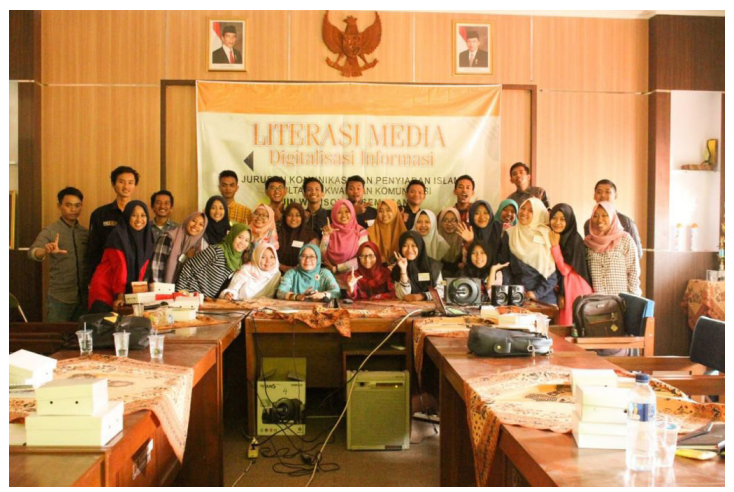

Figure1. Social media literacy counseling's participants

As part of technological innovations, social media give space to anybody to come up with views and echo thoughts that they might not have expressed earlier due to the lack of a means to do so. Social media also serve as a new room for the public to express their thoughts (Putranto, 2020). In this regard, social media have positive and negative impacts. The positive impact is that the public can receive up-to-date information, while the negative impact is that a lot of hoax news spreads in the community. That is why it is important for students who will become propagators to have social media literacy through this counseling activity.

Hoax or false information is found very much because producers spread it. Hoax or false information has become a subject of discussion in online media and social media because it causes public unrest and blurs information. Hence, the truth of information spreading in the community cannot be ensured. Hoax in social media spreads widely when it is taken by a leading website or actor that has many followers.
The speed and characteristic of shareable social media (shareability) play a role in spreading hoax. The rampant hoax news has a negative impact on the public. The content of hoax news is generally related to negative thing, such as provocation, and slander. Hoax targets public emotion to build a negative opinion of a certain party or agency with the aim of creating an uproar (Waluyo \& Muqsith, 2018, Christiany, 2018).

In his address, source person AM, a senior journalist who is also chief of the Central Java Chapter of Indonesian Journalists Association stated hoax news can be controlled and eradicated by launching literacy campaign, initiating to check the fact, and taking legal action to prevent it from spreading. The fact that the Indonesian public are not accustomed to having different opinions is one of the factors that makes them consume hoax easily. Since the past, he said, the Indonesian people have been fond of assembling, chatting and discussing something related to violence, sensuality, drama, mystery and intrigue. Hence, he said, the students must be wary of provocative titles carrying hoax.

To that end, they should look at carefully the address of the website spreading hoax news by checking its URL address. He said it is easier to ask for the responsibility of news published on the website of media outlet verified by the Press Council than that published by fake website that has no clear address. According to the Press Council's records, Indonesia has approximately 48 thousand news and journal websites but less than 400 of them have been verified.

The other issue that needs to be observed is the difference between fact-based news and opinion-based news. Fact is an event supported by witness statement and evidence, while opinion is the view and impression of news writer who tends to be subjective. In the current era of digital technology, not only content in the form of text but also content in the form of photo and video can be manipulated. Sometimes fake news writer edits photos to provoke readers. Therefore, it takes time to check the original of the photos by using Google Search, and employing a drag-and-drop method to the search column of Google Images. The search will present similar pictures found in the internet so that they can be compared.

Of equal importance, the students are advised to take part in the anti-hoax discussion group. In Facebook, there are a number of fanpages and anti-hoax discussion groups, for instance, Anti-Slander, Provocation and Hoax Forum (FAFHH), Fanpage \& Group Indonesian Hoax Buster, Fanpage Indonesian Hoaxes, and Sekoci Group. In these discussion groups, the students can ask whether or not a piece of information can be hoax and see clarification given by other people. All members can give contributions so that the groups will function as crowdsourcing which benefit from the power of many people. 
The other source person, SYL who is the Coordinator of Broadcast Content Section at the Central Java Provincial Information Broadcast Commission (KPID), stated hoax is so dangerous that it must be avoided and deleted from the account of each user soon. Because of hoax phenomenon, the public have become doubtful about the truth of information conveyed by media. In addition, race in speed posting, instastory, tweet, and posting fitness may have an impact on the creation of hoax news. Posting and sharing information without considering social responsibility, hoax phenomenon and spread culture is also one of the factors worsening the presence of hoax information, he said.

In the discussion session, the students enthusiastically asked questions about hoax so that the session took place in a warm, cheerful and dynamic atmosphere. The source persons successfully convinced the students of the danger of hoax. Having been aware of hoax, the students pledged to be selective in consuming information on their social media account. They also vowed to delete hoax news so that a chain of hoax news can be broken from now on.

\section{Conclusion}

After attending this counseling, the students are expected to have responsive personality in using social media and become professional in receiving and spreading information, particularly related to hoax. This counseling has successfully aroused the participants' understanding about the danger of hoax. As prospective propagators, the participants of the counseling pledged not to spread and produce hoax in their propagation messages when they become propagators after graduating from the Faculty of Propagation and Communication at UIN Walisongo, Semarang. The participants expressed gratitude for the counseling since it has broadened their outlook to understand the danger of hoax.

\section{References}

Astrini, A. (2017). Hoax dan Banalitas Kejahatan. Jurnal Transformasi, 2(32), 92-98.

Christiany, J. (2018). Interaksi Komunikasi Hoax di Media Sosial serta Antisipasinya. Jurnal Pekommas, 3(1), $31-44$.

Boese, A. (20020. Museum of Hoax: A Collection of Pranks, Stunts, Deceptions, and Other Wonderful Stories Contrived for the Public from the Middle Ages to the New Millennium, Dutton Adult
Buckingham, D. (2006). Defining Digital Literacy: What do young people need to know about digital media? London: University of London.

Evelina, L. W. (2015). Analisis Isu S (Suku) A (Agama) $\mathrm{R}$ (Ras) A (Antar Golongan) di Media Social Indonesia. Jurnal ULTIMA Comm, 7(1), 107-122.

https://kominfo.go.id/content/detail/28536/kominfomencatat-sebanyak-1028-hoaks-tersebar-terkaitcovid-19/0/sorotan_media (13-8-2020).

https://kominfo.go.id/content/detail/11347/cara-cerdasmencegah-penyebaran-hoaks-di-medsos/0/ sorotan_media (https://databoks.katadata.co.id/ datapublish/2019/05/16/pengguna-internet-diindonesia-2018-bertambah-28-juta).

Kominfo, (2018). Siaran Pers No.53/HM/ KOMINFO/02/2018 Tentang Jumlah Pengguna Internet 2017 Meningkat, Kominfo akan Terus Lakukan Percepatan Pembangunan Broadband.

Kurnia, N., \& Astuti, S. (2017). Peta Gerakan Literasi Digital di Indonesia: Studi Tentang Pelaku, Ragam Kegiatan, Kelompok Sasaran dan Mitra, Jurnal Informasi Kajian Ilmu Komunikasi. 47 (2). 149-166.

Marwan, M. R., \& Ahyad, A. (2016). Analisis penyebaran berita hoax di Indonesia. Jurusan Ilmu Komunikasi, Fakultas Ilmu Komunikasi Universitas Gunadarma, 5(1), 1-16.

Masyarakat Telematika Indonesia (Mastel)., (2017). Hasil Survey Wabah Hoax 2017. Retrieved from: https:// mastel.id/hasil-survey-wabah-hoax-nasional-2017/

Pratama, A.B (2016). Ada 800 Ribu Situs Penyebar Hoax di Indonesia. https://www.cnnindonesia.com/ teknologi/20161229 170130-185-182956/ada-800ribu-situs-penyebar- hoax-di-indonesia/

Putranto, P., \& Ariani, M. (2020). Coaching MSMEs through the Business Development Services Program. PARAHITA: Jurnal Pengabdian kepada Masyarakat, 1(1), 1-7.

Rahadi, D.R. (2017). Perilaku Pengguna dan Informasi Hoax di Media Sosial. Jurnal Manajemen dan Kewirausahaan, 5 (1). 58-70.

Waluyo, R., \& Muqsith, N R. (2018). Sosialisasi Etika Bermedia Sosial untuk Menyikapi Berita Hoax di SMA Muhamadiyah 4 Purbalingga. Purwokerto, Jurnal Manajemen Pendidikan dan Pelatihan, 2 (3). 